Article

\title{
Pedogenic Carbonates and Radiocarbon Isotopes of Organic Carbon at Depth in the Russian Chernozem
}

\author{
Elena A. Mikhailova ${ }^{1, *}$, Ray B. Bryant ${ }^{2}{ }^{(0)}$, John M. Galbraith ${ }^{3}{ }^{(}$, Yang Wang ${ }^{4}$, \\ Christopher J. Post ${ }^{1}$, Olga S. Khokhlova ${ }^{5}$, Mark A. Schlautman ${ }^{6}{ }^{\mathbb{D}}$, Michael P. Cope ${ }^{1}$ \\ and Zhixiong Shen ${ }^{7}$ \\ 1 Department of Forestry and Environmental Conservation, Clemson University, Clemson, SC 29634, USA; \\ cpost@clemson.edu (C.J.P.); mpcope@g.clemson.edu (M.P.C.) \\ 2 USDA-ARS Pasture Systems and Watershed Management Research Unit, University Park, State College, \\ PA 16802, USA; Ray.Bryant@ars.usda.gov \\ 3 Crop and Soil Environmental Science, Virginia Tech, Blacksburg, VA 24061, USA; ttcf@vt.edu \\ 4 Department of Earth, Ocean and Atmospheric Science, Florida State University, Tallahassee, FL 32306, USA; \\ ywang@magnet.fsu.edu \\ 5 Institute of Physical, Chemical and Biological Problems of Soil Science RAS, Pushchino, 142290 Moscow, \\ Russia; akhokhlov@mail.ru \\ 6 Department of Environmental Engineering and Earth Sciences, Clemson University, Anderson, SC 29625, \\ USA; mschlau@clemson.edu \\ 7 Department of Marine Science, Coastal Carolina University, Conway, SC 29528, USA; zshen@coastal.edu \\ * Correspondence: eleanam@clemson.edu; Tel.: +1-864-656-3535
}

Received: 9 October 2018; Accepted: 28 November 2018; Published: 5 December 2018

check for updates

\begin{abstract}
Conversion of native grasslands to agricultural sites has resulted in remarkable changes in soil carbon at depth, but its impact on soil diagnostic horizons is unknown. This study was conducted to radiocarbon date the soil organic carbon (SOC) and quantify pedogenic carbonates in the Russian Chernozem at depth at three sites: a native grassland field (not cultivated for at least 300 years), an adjacent 50-year continuous fallow field in the V.V. Alekhin Central-Chernozem Biosphere State Reserve in the Kursk region of Russia (UNESCO-MAB Biosphere Reserve), and a cropland in the Experimental Station of the Kursk Institute of Agronomy and Soil Erosion Control. All sampled soils were classified as Fine-silty, mixed, frigid Pachic Hapludolls (Haplic Chernozem). The radiocarbon age $\left({ }^{14} \mathrm{C}\right.$ date, $\left.\mathrm{y} \mathrm{BP}\right)$ of SOC was highly variable: in the native grassland field, it varied from post-bomb (A-horizon) to $8011 \pm 54 \mathrm{y}$ BP (C-horizon); in the continuous fallow, it varied from $1569 \pm 41$ y BP (Ap-horizon) to 11,380 \pm 180 y BP (C1-horizon); and in the cropland, it varied from $1055 \pm 38$ y BP (Ap-horizon) to 11,805 \pm 68 y BP (Ck-horizon). Cultivation resulted in morphological/diagnostic changes in the soil profile (conversion of A to Ap; conversion of Bw to Bk horizon) over a 50-year period. These changes are supported by radiocarbon dating of SOC and pedogenic carbonate distribution within the soil profile. The proportion of pedogenic carbonates was highly variable: in the native grassland, it was 27\% (C-horizon); in the continuous fallow, it varied from 53\% (Bk1-horizon) to 72\% (C2-horizon); and in the cropland, it varied from 85\% (A-horizon) to $10 \%$ (Ck-horizon). The radiocarbon age differences with depth among the soils reflect changes in the soil carbon dynamics resulting from cultivation.
\end{abstract}

Keywords: anthropogenic; carbonates; cultivation; ${ }^{14} \mathrm{C}$; grassland; isotopes; pedogenic

\section{Introduction}

Most grasslands have undergone considerable changes due to human activities worldwide [1,2]. Grassland soils of the world store significant amounts of soil organic carbon (SOC) and soil inorganic 
carbon (SIC), and many studies have used radiocarbon dating for determining carbon dynamics [3-6]. For example, radiocarbon dating was used to compare the ${ }^{14} \mathrm{C}$ age of humus from different horizons (down to $60 \mathrm{~cm}$ depth) of cultivated and non-cultivated Chernozems in the Belgorod region of Russia and concluded that the radiocarbon age of soil organic matter (SOM) increased with cultivation due to a lack of input of fresh plant material compared to non-cultivated sites [7]. Another study used radiocarbon and stable carbon isotopes to quantify the rates of labile and inert organic carbon cycling with depth in Mollisols at a restored prairie within an intensively managed landscape within the Critical Zone Observatory in Illinois, USA [8]. Radiocarbon dating was used for various soils in the North American grasslands, including soils from North Dakota, Nebraska, Colorado, Kansas, and Texas, and it was reported that soil depth, and management affected the soil ${ }^{14} \mathrm{C}$ age [3].

Interpretation of radiocarbon ages of SOM can be a challenging task because SOM is the product of ongoing SOM accumulation and decomposition and thus does not meet the basic "closed system" criterion for accurate radiocarbon dating [9]. Radiocarbon dating of SOM provides minimum ages of SOM for the length of soil formation [10-15]. Radiocarbon ages of the SOM are controlled by the rate of carbon cycling in soils, reflecting the input rates and mean residence time (MRT) of gradually accumulating SOC (the carbon of soil humus) rather than the age of the soils $[4,16,17]$. An increase in the activity of carbon exchange processes, and, hence, the rejuvenation of radiocarbon dates, indicate the input of young SOM to the soils, while more ancient dates indicate a decrease in recent SOM. The presence of soil carbonates (disseminated and concretions) can also impact the ${ }^{14} \mathrm{C}$ dating of SOM throughout the soil profile. Presence of carbonates can result in high variability in radiocarbon dates of soil samples $[18,19]$. A study from southeast Australia reported ${ }^{14} \mathrm{C}$ ages of carbonates that were younger than the ages of deposits in which they formed [20]. More recent studies often pretreat the samples using chemical or physical means to remove either carbonates or OM before radiocarbon analysis, which enable separate ${ }^{14} \mathrm{C}$ dating of SOM and SIC.

Traditionally, research has focused on analyzing SOC dynamics without considering SIC and total soil carbon (TC). Soil inorganic carbon was proposed to be included in the ecosystem services framework for the United Nations (UN) Sustainable Development Goals (SDGs) because of its significance in soil fertility (e.g., liming, fertilization, etc.) [21]. In addition to soil fertility, SIC plays an important regulatory ecosystem service by sequestering atmospheric $\mathrm{CO}_{2}$ in the presence of outside sources of $\mathrm{Ca}^{2+}$ and $\mathrm{Mg}^{2+}$ [22-24].

Soil inorganic carbon (e.g., various types of carbonates) can be lithogenic or pedogenic in origin $[25,26]$. While lithogenic carbonates are considered rock derived, pedogenic carbonates can form as a result of dissolution and re-precipitation of lithogenic or newly formed carbonates [26]. Originally, it was thought that SIC required centuries to accumulate $[27,28]$. Pedogenic carbonates were extensively studied in different types of soils primarily in various landscape positions [29,30].

Soil inorganic carbon sequestration was reported as a result of the cultivation of Mollisols of the U.S. Northern Great Plains and the Russian Chernozem [31,32]. Mollisols may be "a significant sink of inorganic carbon through pedogenic carbonate formation, which may partially offset carbon loss from soil organic matter decomposition" [32]. An anthropogenic model of carbonate formation was proposed to explain the carbonate precipitation as a result of cultivation, irrigation, fertilization, and other man-made processes [32]. A test for carbonate biomineralization in desert soils (New Mexico, USA) showed that SIC can be generated in months to years if the soil environment is suitable [28]. In addition to cultivation, long-term irrigated farming can significantly increase SOC and SIC in agricultural soils [33].

Increasingly, research is incorporating SIC and TC in soil carbon dynamics studies [34]. For example, [35] reported that $51 \%$ of total cultivated soil surfaces experienced $C$ loss and an increase $(\sim 10 \%)$ in SIC storage in irrigated soils in northwestern China. A study by [36] examined the carbon (SOC, SIC, and TC) allocation in a temperate slope-floodplain catena under agricultural use, and called for monitoring of carbon pools in these landform positions for quick response to environmental and anthropogenic changes. 
Previous research on SOC, SIC, and TC has focused primarily on quantifying carbon stocks with limited insight into the pedological consequences of agricultural changes in specific soil horizons. A study by [37] proposed to differentiate pedology "per se" from experimental pedology. In contrast to pedology "per se", which is focused on soil as a natural body, experimental pedology uses manipulative experiments (including historical experiments) to test pedological questions and hypotheses. Based on principles of experimental pedology, this study addresses the following research questions: (1) Can cultivation/agricultural use result in pedological changes within a soil profile with consequent changes in the diagnostic soil horizons and characteristics? (2) How fast can these changes occur (e.g., less than a half-century)? These questions can be evaluated based on a unique long-term field study conducted in the V.V. Alekhin Central-Chernozem Biosphere State Reserve (UNESCO-MAB Biosphere Reserve), and the Experimental Station of the Kursk Institute of Agronomy and Erosion Control in the Kursk region of Russia. Soil samples were collected in 1997 [38] and radiocarbon dated in 2005. A study by [38] have provided a detailed description of the study site as well as sampling and laboratory procedures. Previous research by [39] reported radiocarbon dates for the native steppe (grassland) located in the V.V. Alekhin Central-Chernozem Biosphere State Reserve (UNESCO-MAB Biosphere Reserve) (Table 1).

Table 1. Radiocarbon data for Haplic Chernozem/Typic Hapludoll located in the Kursk ( $36^{\circ} 10^{\prime}$ E; $51^{\circ} 45^{\prime} \mathrm{N}$ ) native steppe with $\mathrm{MAP}^{\mathrm{a}}=715 \mathrm{~mm}$ and $\mathrm{MAT}^{\mathrm{b}}=5.3^{\circ} \mathrm{C}$ (uncalibrated data from $[39,40]$ ).

\begin{tabular}{ccc}
\hline Depth $\mathbf{( c m )}$ & $\boldsymbol{\delta}^{\mathbf{1 3}} \mathbf{C} \mathbf{( \% )}$ & ${ }^{\mathbf{1 4}} \mathbf{C}$ Age for Soil without Carbonates $(\mathbf{y}$ BP) \\
\hline $10-20$ & -25.75 & $1680 \pm 60$ \\
$30-40$ & -26.20 & $2950 \pm 80$ \\
$50-60$ & -25.88 & $2970 \pm 110$ \\
$70-80$ & -24.92 & $4020 \pm 90$ \\
$120-130$ & - & $6100 \pm 200$ \\
$140-150$ & - & $6700 \pm 100$ \\
\hline
\end{tabular}

${ }^{\mathrm{a}} \mathrm{MAP}$, mean annual precipitation; ${ }^{\mathrm{b}} \mathrm{MAT}$, mean annual temperature.

The objectives of this study were to address the above questions by quantifying the depth distributions and radiocarbon ages of SOC, and pedogenic carbonates at three sites in the Russian Chernozem: a native grassland field (not cultivated for at least 300 years), an adjacent 50-year continuous fallow field in the V.V. Alekhin Central-Chernozem Biosphere State Reserve in the Kursk region of Russia (UNESCO-MAB Biosphere Reserve), and a cropland in the Experimental Station of the Kursk Institute of Agronomy and Soil Erosion Control.

\section{Materials and Methods}

\subsection{Field Sites and Sampling Procedure}

Three fields were sampled in the Kursk region of Russia in the summers of 1997 and 1998: a native grassland, a 50-year continuous fallow field, and cropland (Figure 1). The Köppen climate classification subtype for the climate in the Kursk region is "Dfb" (warm-summer humid continental climate), with a mean annual precipitation of $587 \mathrm{~mm}$, and a mean annual air temperature of $5.4{ }^{\circ} \mathrm{C}$ [41,42]. Sampling fields were selected with a similar soil type and landscape position. All sampled soils were classified as Fine-silty, mixed, frigid Pachic Hapludoll [43] or Haplic Chernozem [44]. One of the sampled soil profiles exhibited signs of bioturbation ("krotovinas"), which is a common phenomenon in the steppe landscapes [45].

The first two fields (native grassland, and a 50-year continuous fallow field) are located in the Streletskyi section of the V.V. Alekhin Central-Chernozem Biosphere State Reserve (UNESCO-MAB Biosphere Reserve) at $51^{\circ} \mathrm{N} 36^{\circ}$ E, approximately $18 \mathrm{~km}$ south of the city of Kursk [46]. Elevation of these sites is approximately $264 \mathrm{~m}$ above mean sea level [47]. The native grassland with high plant species richness has been protected from use since 1935, and it was used as a pasture before 1935 . 
The 50-year continuous fallow field (about 0.8 -ha) is located about $50 \mathrm{~m}$ from the native grassland site, and it has been continuously plowed (1-2 times a month) since 1947 with the disk cultivator to a 20-cm depth [38]. The third field (cropland) is located in the Experimental Station of the Kursk Institute of Agronomy and Soil Erosion Control. This field has been continuously plowed to a 30-cm depth, fertilized (including manure applications), and cropped (corn, sunflower, barley, clover, winter wheat, soybeans, sugar beets etc.) for at least 100 years [38].

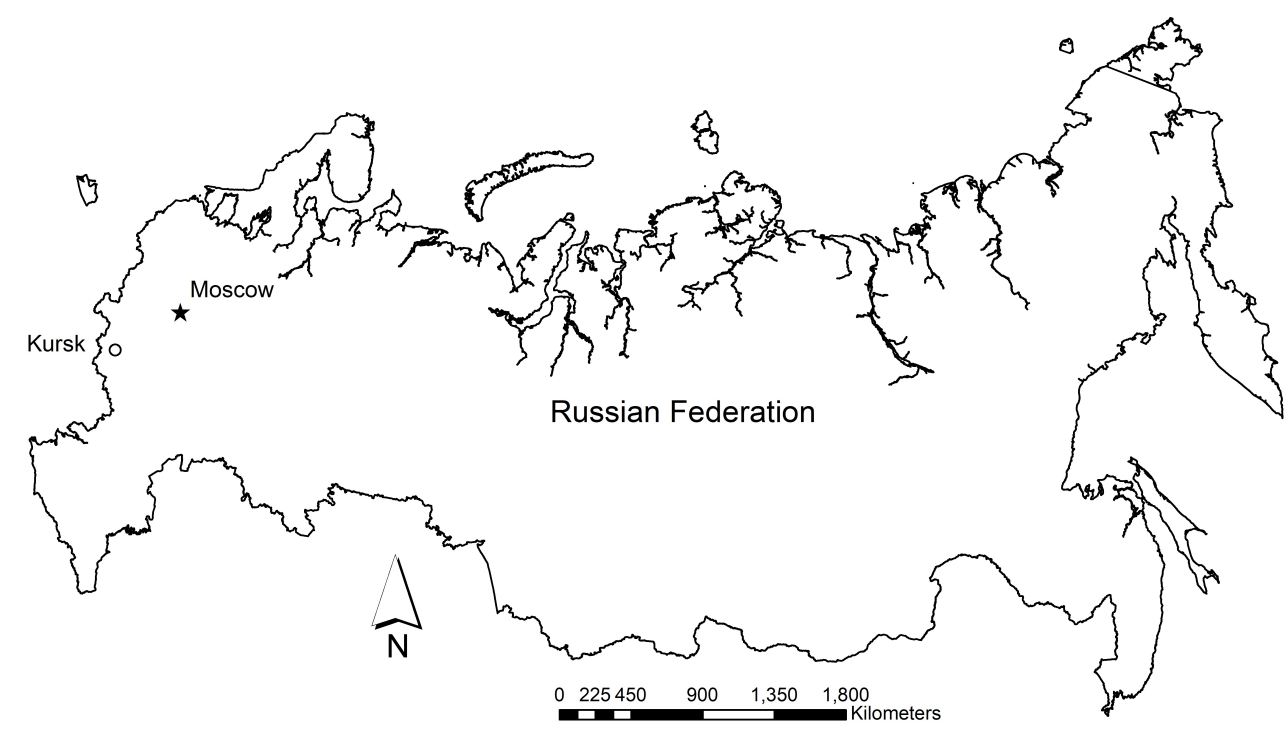

Figure 1. Location of the study area.

All fields were sampled on a radial grid, whose orientation was determined by randomly selecting an angle from 360 degrees [38]. Deep soil cores were collected at the center and at $20 \mathrm{~m}$ from the center at all three sites. All samples were collected to a depth of $2 \mathrm{~m}$ using a hand probe $5 \mathrm{~cm}$ in diameter. Soil cores were dissected into 10-cm increments, and the following data were recorded in the field: upper and lower boundary of the soil horizon, moist and dry color (Munsell color chart), reaction to $10 \%$ $\mathrm{HCl}$, and presence of carbonate accumulations. Detailed descriptions of the study area, and land-use management history have been published previously $[38,48,49]$.

\subsection{Laboratory Methods and Calculations}

One representative soil profile was selected from each site for further chemical and physical analyses. Concretions were handpicked from the bulk soil samples when found. Soil analyses were performed on each 10-cm depth increment, but summarized by soil horizon (Tables 2 and 3). Soil samples from each 10-cm depth increment were air dried, manually crushed, and passed through a 2-mm sieve. Particle-size distribution was determined by the pipette method after pretreating for carbonates (Table 2). Soil pH was measured from a 1:1 soil/water suspension [50] (Table 2). Carbonate content in the bulk soil and clay fraction was determined by the pressure-calcimeter method, which is a standard method [51], and it was only used for soil classification purposes in this study. Since single measurements were done on a composite soil sample, the analytic error is not available and cannot be calculated. The pressure-calcimeter data were not used to quantify the pedogenic carbonates because it is necessary to determine isotopic composition of the carbon using mass spectrometry. Soil organic carbon (SOC) and TC were determined by dry combustion-mass spectrometry using a Robo-prep-Tracemass system, Europa Scientific (Cheshire, UK), with SIC calculated by the difference. Samples that reacted to $10 \% \mathrm{HCl}$ were treated with $4 \mathrm{M} \mathrm{HCl}$ for carbonate removal before analysis [38]. 
Table 2. Selected soil properties with depth and site in the representative soil profile: mean \pm standard deviation (adapted from [38]).

\begin{tabular}{|c|c|c|c|c|c|c|c|}
\hline Site/Horizon & Depth (cm) & $\mathbf{n}$ & $\mathrm{pH}$ in Water & Sand $(\%)$ & Silt (\%) & Clay (\%) & USDA Textural Class $^{a}$ \\
\hline \multicolumn{8}{|l|}{ Native } \\
\hline $\mathrm{A}$ & $0-50$ & 5 & $6.1 \pm 0.2$ & $2.0 \pm 0.5$ & $66.8 \pm 0.3$ & $31.2 \pm 0.6$ & $\mathrm{SiCL}^{\mathrm{b}}$ \\
\hline $\mathrm{AB}$ & $50-90$ & 4 & $6.3 \pm 0.0$ & $0.8 \pm 0.1$ & $66.9 \pm 0.5$ & $32.3 \pm 0.5$ & $\mathrm{SiCL}$ \\
\hline BA & $90-120$ & 3 & $6.8 \pm 0.5$ & $0.8 \pm 0.1$ & $67.8 \pm 0.9$ & $31.4 \pm 1.0$ & SiCL \\
\hline Bw & $120-150$ & 3 & $7.0 \pm 0.4$ & $0.9 \pm 0.2$ & $70.1 \pm 3.5$ & $29.0 \pm 3.6$ & $\mathrm{SiCL}$ \\
\hline $\mathrm{C}$ & $150-200$ & 5 & $8.5 \pm 0.3$ & $1.1 \pm 0.2$ & $76.8 \pm 1.4$ & $22.1 \pm 1.3$ & SiL \\
\hline \multicolumn{8}{|l|}{ Fallow } \\
\hline Ap & $0-20$ & 2 & $5.9 \pm 0.2$ & $0.7 \pm 0.1$ & $65.6 \pm 0.1$ & $33.7 \pm 0.0$ & SiCL \\
\hline A & $20-50$ & 3 & $6.9 \pm 0.4$ & $1.1 \pm 0.7$ & $64.9 \pm 0.4$ & $34.0 \pm 0.6$ & $\mathrm{SiCL}$ \\
\hline $\mathrm{AB}$ & $50-80$ & 3 & $7.6 \pm 0.3$ & $1.0 \pm 0.1$ & $66.8 \pm 2.5$ & $32.2 \pm 2.4$ & SiCL \\
\hline Bk1 & $80-120$ & 4 & $8.3 \pm 0.1$ & $1.2 \pm 0.6$ & $72.3 \pm 3.5$ & $26.5 \pm 3.2$ & $\mathrm{SiL}$ \\
\hline $\mathrm{Bk} 2$ & $120-150$ & 3 & $8.4 \pm 0.1$ & $1.8 \pm 0.6$ & $69.4 \pm 2.1$ & $28.8 \pm 1.8$ & SiCL \\
\hline $\mathrm{C} 1$ & 150-190 & 4 & $8.4 \pm 0.1$ & $2.4 \pm 0.4$ & $67.1 \pm 2.8$ & $30.5 \pm 3.3$ & SiCL \\
\hline $\mathrm{C} 2$ & $190-210$ & 2 & $8.5 \pm 0.0$ & $4.7 \pm 1.4$ & $73.3 \pm 6.2$ & $22.0 \pm 4.8$ & SiL \\
\hline \multicolumn{8}{|l|}{ Cropland } \\
\hline Ap & $0-30$ & 3 & $7.9 \pm 0.1$ & $1.1 \pm 0.4$ & $69.0 \pm 0.3$ & $29.9 \pm 0.3$ & SiCL \\
\hline $\mathrm{A}$ & $30-70$ & 4 & $8.4 \pm 0.2$ & $0.9 \pm 0.3$ & $80.4 \pm 3.1$ & $18.7 \pm 3.2$ & SiL \\
\hline $\mathrm{AB}$ & $70-90$ & 2 & $8.6 \pm 0.1$ & $1.3 \pm 0.6$ & $77.4 \pm 6.7$ & $21.3 \pm 6.1$ & SiL \\
\hline Bk1 & $90-120$ & 3 & $8.6 \pm 0.0$ & $1.5 \pm 0.3$ & $74.3 \pm 1.1$ & $24.2 \pm 1.1$ & $\mathrm{SiL}$ \\
\hline $\mathrm{Bk} 2$ & $120-190$ & 7 & $8.6 \pm 0.1$ & $1.7 \pm 0.4$ & $73.7 \pm 1.9$ & $24.6 \pm 2.1$ & $\mathrm{SiL}$ \\
\hline $\mathrm{Ck}$ & 190-200 & 1 & 8.4 & 1.2 & 75.6 & 23.2 & $\mathrm{SiL}$ \\
\hline
\end{tabular}

Table 3. Selected soil properties with depth and site relevant to horizon differentiation in the representative soil profile (adapted from [38]).

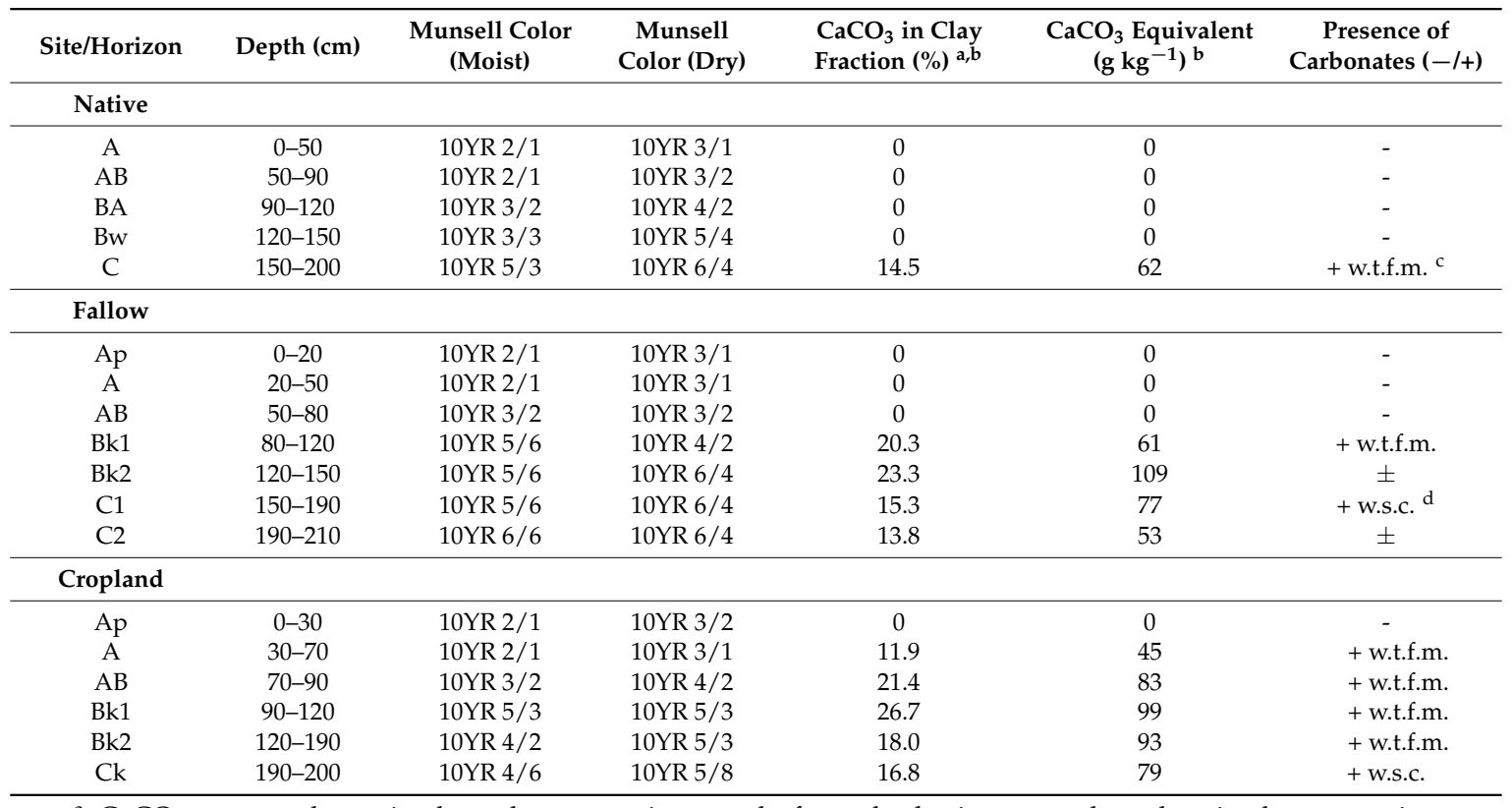

${ }^{a} \mathrm{CaCO}_{3}$ content determined on the composite sample from the horizon samples taken in the proportion corresponding to the number of samples in the horizon. ${ }^{\mathrm{b}}$ Carbonate content in the bulk soil and clay fraction was determined by the pressure-calcimeter method [51], and used to classify the diagnostic horizons. ${ }^{\mathrm{c}}$ w.t.f.m. $=$ secondary calcium carbonate accumulation in the form of white threads, films, and masses. ${ }^{d}$ w.s.c. $=$ secondary calcium carbonate accumulation in the form of white spherical concretions.

Bulk soil samples, samples with carbonate removed, and carbonate concretions were radiocarbon dated using the accelerator mass spectrometer (AMS) technique $[52,53]$ at the National Science Foundation (NSF) - Arizona Accelerator Mass Spectrometry (AMS) Laboratory in 2005. In addition to radiocarbon dating, this analysis provided $\delta^{13} \mathrm{C}$ measurements for bulk soil samples, samples with carbonates removed, and carbonate concretions. 
Stable $C$ isotope data were reported in the standard per mil notation relative to the Pee Dee Belemnite (PDB) standard as:

$$
\delta^{13} \mathrm{C}=\left(\frac{R_{\text {sample }}}{R_{P D B}}-1\right) \times 100
$$

and ${ }^{14} \mathrm{C}$ data were expressed as [54]:

$$
\Delta^{14} C=\left(\frac{R_{\text {sample }}}{R_{\text {std }}}-1\right) \times 1000
$$

where $\Delta^{14} C$ is the per mil value for ${ }^{14} C$ content [54], $R_{\text {sample }}$ is the ${ }^{14} C /{ }^{12} C$ ratio in the sample, and $R_{\text {std }}$ is the absolute ratio in the isotopic standard (NBS oxalic acid), or:

$$
\text { pMC (percent modern carbon })=\frac{A_{S N}}{A_{a b s}} * 100
$$

where $A_{S N}$ is the ${ }^{14} \mathrm{C}$ activity in the sample normalized to $\delta^{13} \mathrm{C}$ and $A_{a b s}$ is the absolute ${ }^{14} \mathrm{C}$ activity in the international isotopic standard (NBS oxalic acid).

The ${ }^{14} \mathrm{C}$ age was calculated from Equation [54]:

$$
\text { Radiocarbon age }=-8033 \ln \left(\frac{p M C}{100}\right)-\frac{y-1950}{1.03}
$$

where $y$ is the year of ${ }^{14} \mathrm{C}$ measurement. The radiocarbon data are reported as percent modern, and corresponding conventional radiocarbon $\left({ }^{14} \mathrm{C}\right)$ ages given as years before present $(\mathrm{y} \mathrm{BP})$ and the present is $\mathrm{AD} 1950[54,55]$.

Pedogenic carbonates were estimated using Equation [56]:

$$
P C=\frac{\delta^{13} C_{(\text {soil })}-\delta^{13} C_{(\text {par.mat. })}}{\delta^{13} C_{(\text {ped. })}-\delta^{13} C_{(\text {par.mat. })}} \times 100(\%)
$$

where $P C$ is the proportion of the total carbonate that is pedogenic (\%), $\delta^{13} C_{(\text {soil) }}$ is the measured bulk carbonate value for a particular soil depth (\%),$\delta^{13} \mathrm{C}_{\text {(par.mat.) }}$ is the measured bulk carbonate value of the parent material (\%), and $\delta^{13} C_{(\text {ped.) }}$ is the measured pedogenic carbonate value of $-10.9 \%$ [31]. The value of $\delta^{13} C_{\text {(par.mat.) }}$ for the loess parent material was $-4.5 \%$ (measured in this study at 200-cm depth).

\section{Results}

\subsection{Soil Types under Different Uses}

All soils under different uses were classified as Fine-silty, mixed, frigid Pachic Hapludolls (Haplic Chernozem). Representative soil profiles have developed on loess parent material and showed silty clay loam (SiCL) and silt loam (SiL) textural classes with no coarse fragments found in the soil (Table 2). Native and fallow sites were dominated by silty clay loam (SiCL) textural classes compared to cropland, which was dominated by silt loam (SiL) textures (Table 2). Soil pH increased with depth from moderately and slightly acidic (5.9-6.1) in the native and fallow sites to moderately and strongly alkaline (8.4-8.5) (Table 2). In the cropland site, $\mathrm{pH}$ also increased with depth from moderately alkaline to strongly alkaline (Table 2). Depth to carbonates decreased with the intensity of agricultural use: native $(150 \mathrm{~cm})>$ fallow $(80 \mathrm{~cm})>$ cropland $(30 \mathrm{~cm})$. There are morphological/diagnostic differences between soil profiles: conversion of A (native) to Ap horizons (fallow and cropland), and conversion of $\mathrm{Bw}$ (cambic horizon) in native to Bk1, Bk2 (calcic horizons) in fallow and cropland sites (Tables 3 and 4). 
Table 4. Diagnostic horizons and characteristics of cambic and calcic horizons (modified from Keys to Soil Taxonomy [57]).

\begin{tabular}{|c|c|}
\hline Cambic Horizon (Bw) & Calcic Horizon (Bk) \\
\hline $\begin{array}{l}\text { A cambic horizon is the result of physical alterations, chemical } \\
\text { transformations, or removals or of a combination of two or more } \\
\text { of these processes. }\end{array}$ & $\begin{array}{l}\text { he calcic horizon is an illuvial horizon in which } \\
\text { econdary calcium carbonate or other carbonates } \\
\text { ave accumulated to a significant extent }\end{array}$ \\
\hline $\begin{array}{l}\text { Required Characteristics: } \\
\text { The cambic horizon is an altered horizon } 15 \mathrm{~cm} \text { or thicker. If it is } \\
\text { composed of lamellae, the combined thickness of the lamellae } \\
\text { must be } 15 \mathrm{~cm} \text { or more. In addition, the cambic horizon must } \\
\text { meet all of the following: } \\
\text { 1. Has a texture class of very fine sand, loamy very fine sand, } \\
\text { or finer; and } \\
\text { 2. Shows evidence of alteration in one of the following forms: } \\
\text { a. Aquic conditions within } 50 \mathrm{~cm} \text { of the soil surface or artificial } \\
\text { drainage and all the following: } \\
\text { (1) Soil structure or the absence of rock structure, including fine } \\
\text { stratifications ( } 5 \text { mm or less thick), in more than one-half of the } \\
\text { volume; and } \\
\text { (2) Colors that do not change on exposure to air; and } \\
\text { (3) Dominant color, moist, on faces of peds or in the matrix } \\
\text { as follows: } \\
\text { (a) Value of } 3 \text { or less and neutral colors with no hue (N) and } \\
\text { zero chroma; or } \\
\text { (b) Value of } 4 \text { or more and chroma of } 1 \text { or less; or } \\
\text { (c) Any value, chroma of } 2 \text { or less, and redox concentrations; or } \\
\text { b. Does not have the combination of aquic conditions within } \\
50 \text { cm of the soil surface or artificial drainage and colors, moist, } \\
\text { as defined in item } 2 \text {-a-(3) above, and has soil structure or the } \\
\text { absence of rock structure, including fine } \\
\text { stratifications (5 mm or less thick), in more than one-half of the } \\
\text { volume and one or more of the following properties: } \\
\text { (1) Higher chroma, higher value, redder hue, or higher clay } \\
\text { content than the underlying horizon or an overlying horizon; or } \\
\text { (2) Evidence of the removal of carbonates or gypsum; and } \\
3 \text {. Has properties that do not meet the requirements for an } \\
\text { anthropic, histic, folistic, melanic, mollic, plaggen, or umbric } \\
\text { epipedon, a duripan or fragipan, or an argillic, calcic, gypsic, } \\
\text { natric, oxic, petrocalcic, petrogypsic, placic, salic, spodic, } \\
\text { or sulfuric horizon; and } \\
4 \text {. Is not part of an Ap horizon and does not have a brittle } \\
\text { manner of failure in more than } 60 \text { percent of the matrix. }\end{array}$ & $\begin{array}{l}\text { Required Characteristics: } \\
\text { The calcic horizon: } \\
\text { 1. Is } 15 \mathrm{~cm} \text { or thicker; and } \\
\text { 2. Has one or more of the following: } \\
\text { a. } 15 \text { percent or more (by weight, fine-earth fraction) } \\
\mathrm{CaCO}_{3} \text { equivalent, and its } \mathrm{CaCO}_{3} \text { equivalent is } \\
5 \text { percent or } \\
\text { more (absolute) higher than that of an underlying } \\
\text { horizon; or } \\
\text { b. } 15 \text { percent or more (by weight, fine-earth fraction) } \\
\text { CaCO } \mathrm{C}_{3} \text { equivalent and } 5 \text { percent or more (by volume) } \\
\text { identifiable secondary carbonates; or } \\
\text { c. } 5 \text { percent or more (by weight, fine-earth fraction) } \\
\text { calcium carbonate equivalent and: } \\
\text { (1) Has less than } 18 \text { percent clay in the fine-earth } \\
\text { fraction; and } \\
\text { (2) Meets the criteria for a sandy, sandy-skeletal, } \\
\text { coarse loamy, or loamy-skeletal particle-size class } \\
\text { (defined in chapter } 17) \text {; and } \\
\text { (3) Has } 5 \text { percent or more (by volume) identifiable } \\
\text { secondary carbonates or a calcium carbonate } \\
\text { equivalent (by weight, fine-earth fraction) that is } \\
5 \text { percent or more (absolute) higher than that of an } \\
\text { underlying horizon; and } \\
\text { 3. Is not cemented or indurated in any part by } \\
\text { carbonates, with or without other cementing agents, } \\
\text { or is cemented in some part and the cemented part } \\
\text { satisfies one of the following: } \\
\text { a. It is characterized by so much lateral discontinuity } \\
\text { that roots can penetrate through non-cemented zones } \\
\text { or along vertical fractures with a horizontal spacing } \\
\text { of less than } 10 \text { cm; or } \\
\text { b. The cemented layer is less than } 1 \text { cm thick and } \\
\text { consists of a laminar cap underlain by a lithic or } \\
\text { paralithic contact; or } \\
\text { c. The cemented layer is less than } 10 \text { cm thick. }\end{array}$ \\
\hline
\end{tabular}

\subsection{Soil Organic Carbon (SOC) under Different Uses}

Soil OC concentrations decreased with depth at all sites from 3-4\% to 1.5-1.8\% (Table 5). Results from radiocarbon analysis showed that the ${ }^{14} \mathrm{C}$ content of the bulk OC generally decreased with depth at all sites (Figure 2). The radiocarbon age of SOC was highly variable: in the native grassland site, it varied from post-bomb to $8011 \pm 54$ y BP; in the continuous fallow, it varied from $1569 \pm 41$ y BP to $11,380 \pm 180 \mathrm{y} \mathrm{BP}$; and in the continuously cropped field, it varied from $1055 \pm 38 \mathrm{y} \mathrm{BP}$ to $11,805 \pm 68$ y BP (Table 6, Figures 2 and 3). The radiocarbon ages of SOC at various depths in the native grassland were similar to radiocarbon ages reported by [39] for the same site (Table 1). The radiocarbon age $\left({ }^{14} \mathrm{C}\right.$ date, y BP) of SOC is older for the cultivated sites compared to the native field for almost all soil horizons. This trend demonstrates the process of "aging" of SOM in the cultivated sites with limited plant residue input and accelerated decomposition of SOM relative to the native soil. 
Table 5. Soil carbon (mean \pm standard deviation) distribution with depth and site in the representative soil profiles.

\begin{tabular}{|c|c|c|c|c|c|c|}
\hline Site/Horizon & Depth (cm) & $\mathbf{n}$ & Total C (\%) ${ }^{a}$ & $\begin{array}{c}\text { Organic } C \\
(\%)^{a}\end{array}$ & $\begin{array}{c}\text { Inorganic } C \\
(\%)^{a}\end{array}$ & $\begin{array}{l}\text { Pedogenic Carbonate } \\
(\%)^{b}\end{array}$ \\
\hline \multicolumn{7}{|l|}{ Native } \\
\hline A & $0-50$ & 5 & $4.49 \pm 0.97$ & $4.49 \pm 0.97$ & 0 & 0 \\
\hline $\mathrm{AB}$ & $50-90$ & 4 & $2.70 \pm 0.43$ & $2.70 \pm 0.43$ & 0 & 0 \\
\hline BA & $90-120$ & 3 & $1.53 \pm 0.23$ & $1.53 \pm 0.23$ & 0 & 0 \\
\hline $\mathrm{Bw}$ & $120-150$ & 3 & $1.20 \pm 0.16$ & $1.12 \pm 0.11$ & 0 & 0 \\
\hline $\mathrm{C}$ & 150-200 & 5 & $1.71 \pm 0.14$ & $0.61 \pm 0.14$ & $1.10 \pm 0.20$ & $27 \pm 8$ \\
\hline \multicolumn{7}{|l|}{ Fallow } \\
\hline Ap & $0-20$ & 2 & $3.38 \pm 0.28$ & $3.38 \pm 0.28$ & 0 & 0 \\
\hline A & $20-50$ & 3 & $3.09 \pm 0.33$ & $3.09 \pm 0.33$ & 0 & 0 \\
\hline $\mathrm{AB}$ & $50-80$ & 3 & $2.15 \pm 0.10$ & $2.08 \pm 0.21$ & 0 & 0 \\
\hline Bk1 & $80-120$ & 4 & $2.33 \pm 0.38$ & $1.14 \pm 0.31$ & $1.19 \pm 0.64$ & $53 \pm 23$ \\
\hline Bk2 & $120-150$ & 3 & $2.30 \pm 0.22$ & $0.66 \pm 0.02$ & $1.64 \pm 0.21$ & $53 \pm 7$ \\
\hline $\mathrm{C} 1$ & 150-190 & 4 & $1.45 \pm 0.08$ & $0.46 \pm 0.02$ & $0.99 \pm 0.07$ & $68 \pm 13$ \\
\hline $\mathrm{C} 2$ & $190-210$ & 2 & $1.52 \pm 0.28$ & $0.31 \pm 0.13$ & $1.22 \pm 0.15$ & $72 \pm 3$ \\
\hline \multicolumn{7}{|l|}{ Cropland } \\
\hline Ap & $0-30$ & 3 & $3.32 \pm 0.09$ & $3.32 \pm 0.09$ & 0 & 0 \\
\hline A & $30-70$ & 4 & $3.19 \pm 0.17$ & $2.40 \pm 0.15$ & $0.79 \pm 0.17$ & $85 \pm 16$ \\
\hline $\mathrm{AB}$ & 70-90 & 2 & $3.21 \pm 0.01$ & $1.91 \pm 0.08$ & $1.30 \pm 0.07$ & $81 \pm 1$ \\
\hline Bk1 & $90-120$ & 3 & $2.95 \pm 0.18$ & $1.20 \pm 0.16$ & $1.75 \pm 0.08$ & $54 \pm 14$ \\
\hline Bk2 & 120-190 & 7 & $2.25 \pm 0.25$ & $0.71 \pm 0.14$ & $1.55 \pm 0.13$ & $20 \pm 11$ \\
\hline $\mathrm{Ck}$ & 190-200 & 1 & 1.82 & 0.51 & 1.31 & 10 \\
\hline
\end{tabular}

a Soil organic carbon (SOC) and total C (TC) were determined by dry combustion-mass spectrometry using a Robo-prep-Tracemass system, Europa Scientific (Cheshire, UK), with soil inorganic carbon (SIC) calculated by the difference. ${ }^{b}$ Pedogenic carbonates were determined using Equation (5).

Table 6. Soil ${ }^{14} \mathrm{C}$ date with depth and site for the representative soil profile (sampling date: 1997; year of ${ }^{14} \mathrm{C}$ measurements: 2005).

\begin{tabular}{|c|c|c|c|c|c|c|c|}
\hline $\begin{array}{l}\text { Depth } \\
\text { (cm) }\end{array}$ & $\begin{array}{c}\text { Soil } \\
\text { Horizon }\end{array}$ & $\begin{array}{c}{ }^{14} \mathrm{C} \text { Date for Soil } \\
\text { without Carbonates } \\
\left({ }^{14} \mathrm{C} \text { y BP }\right)\end{array}$ & $\begin{array}{l}\text { Percent } \\
\text { Modern } \\
(\%)\end{array}$ & $\Delta^{14} \mathrm{C}(\% 0)$ & $\begin{array}{c}{ }^{14} \text { C date for Bulk Soil } \\
\text { (with Carbonates) } \\
\left({ }^{14} \text { C y BP) }\right.\end{array}$ & $\begin{array}{l}\text { Percent } \\
\text { Modern } \\
(\%)\end{array}$ & $\Delta^{14} \mathrm{C}(\%)$ \\
\hline \multicolumn{8}{|l|}{ Native } \\
\hline $0-10$ & $\mathrm{~A}$ & Post-bomb & 103 & 29.3 & - & - & - \\
\hline $30-40$ & A & $1465 \pm 39$ & 83 & -172.3 & - & - & - \\
\hline $60-70$ & $\mathrm{AB}$ & $2669 \pm 41$ & 71 & -287.5 & - & - & - \\
\hline $100-110$ & $\mathrm{BA}$ & $4206 \pm 44$ & 59 & -411.5 & - & - & - \\
\hline 130-140 & $\mathrm{Bw}$ & $5302 \pm 46$ & 51 & -486.6 & - & - & - \\
\hline $140-150$ & $\mathrm{Bw}$ & $4207 \pm 44$ & 59 & -411.5 & $9700 \pm 100$ & 30 & -703.1 \\
\hline $160-170$ & $\mathrm{C}$ & $6031 \pm 48$ & 47 & -531.1 & $10,950 \pm 63$ & 25 & -745.8 \\
\hline 180-190 & $\mathrm{C}$ & $8011 \pm 54$ & 37 & -633.5 & $11,436 \pm 65$ & 24 & -760.8 \\
\hline \multicolumn{8}{|l|}{ Fallow } \\
\hline $0-10$ & Ap & $1569 \pm 41$ & 82 & -182.9 & - & - & - \\
\hline $30-40$ & $\mathrm{~A}$ & $2369 \pm 41$ & 74 & -260.3 & - & - & - \\
\hline $60-70$ & $\mathrm{AB}$ & $3697 \pm 42$ & 63 & -373.1 & - & - & - \\
\hline $90-100$ & Bk1 & $3883 \pm 43$ & 61 & -384.4 & $8298 \pm 81$ & 35 & -646.5 \\
\hline $130-140$ & $\mathrm{Bk} 2$ & $5937 \pm 54$ & 47 & -526.6 & $8747 \pm 54$ & 33 & -665.6 \\
\hline 170-180 & $\mathrm{C} 1$ & $11,380 \pm 180$ & 24 & -758.9 & $10,902 \pm 63$ & 26 & -744.3 \\
\hline $200-210$ & $\mathrm{C} 2$ & $7820 \pm 190$ & 38 & -624.8 & $9198 \pm 70$ & 32 & -683.9 \\
\hline \multicolumn{8}{|l|}{ Cropland } \\
\hline $0-10$ & Ap & $1055 \pm 38$ & 87 & -128.9 & - & - & - \\
\hline $30-40$ & $\mathrm{~A}$ & $2410 \pm 41$ & 74 & -264.0 & $2675 \pm 45$ & 71 & -288.0 \\
\hline $60-70$ & A & $4224 \pm 49$ & 59 & -412.9 & $3964 \pm 46$ & 61 & -393.5 \\
\hline $100-110$ & $\mathrm{Bk} 1$ & $6308 \pm 49$ & 45 & -547.0 & $7888 \pm 53$ & 37 & -627.9 \\
\hline $120-130$ & $\mathrm{Bk} 2$ & $5098 \pm 46$ & 53 & -473.4 & $8511 \pm 54$ & 34 & -655.7 \\
\hline $160-170$ & $\mathrm{Bk} 2$ & $7118 \pm 48$ & 41 & -590.4 & $11,043 \pm 64$ & 25 & -748.8 \\
\hline 190-200 & $\mathrm{Ck}$ & $11,805 \pm 68$ & 23 & -771.5 & $10,991 \pm 68$ & 25 & -747.2 \\
\hline
\end{tabular}



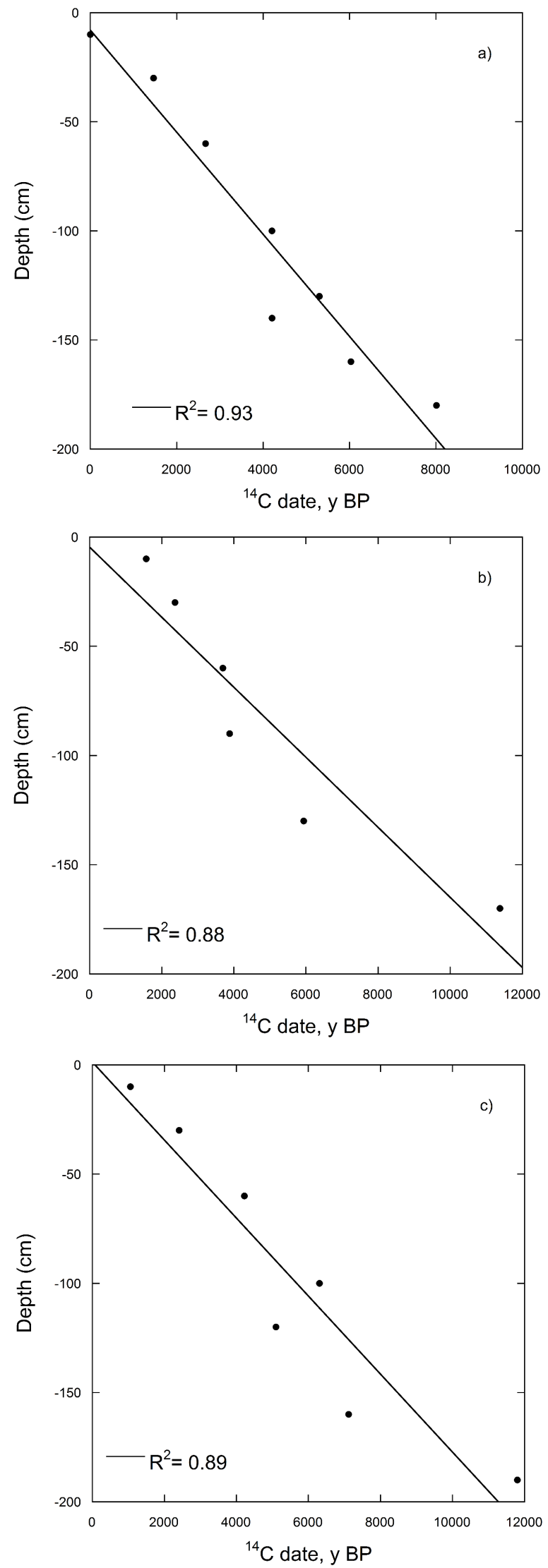

Figure 2. Radiocarbon ages $\left({ }^{14} \mathrm{C}, \mathrm{y} \mathrm{BP}\right)$ of soil (treated for carbonates) at various depths and different sites: (a) native, (b) fallow, and (c) cropland. 

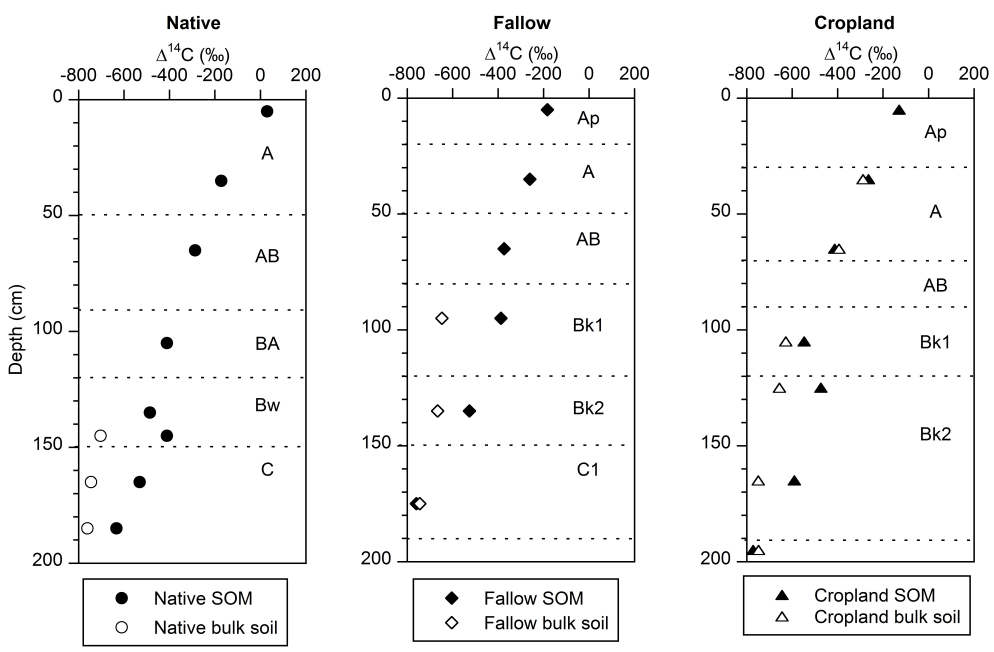

Figure 3. Distribution of $\Delta^{14} \mathrm{C}$ values with depth under different sites.

\subsection{Soil Inorganic Carbon (SIC) under Different Uses}

Concentrations of SIC increased with depth at all sites from 0 to 1-1.3\% (Table 5). The depth to SIC and pedogenic carbonates varied by site: in the native grassland, SIC was found at depths of 140-150 cm compared to the fallow site at depths of 90-100 cm and in the cropland, at depths of 30-40 cm (Table 5). The proportion of pedogenic carbonates increased with depth in the fallow and decreased in the cropland (Table 5). The concentration of pedogenic carbonates was highly variable: in the native grassland, it was $27 \%$ (C-horizon); in the continuous fallow, it varied from $53 \%$ (Bk1-horizon) to $72 \%$ (C2-horizon), and in the cropland, it varied from $85 \%$ (A-horizon) to 10\% (Ck-horizon). Disseminated carbonates were not radiocarbon dated in this study. Radiocarbon dates of bulk soil (with carbonates) are shown in Table 6.

Only white spherical carbonate concretions $(98-100 \%$ pedogenic carbonate) were radiocarbon dated. The ${ }^{14} \mathrm{C}$ ages of concretions found in the fallow and cropland sites varied from $1909 \pm 40 \mathrm{y}$ BP to $2285 \pm 40$ y BP, even though they were found in soils of a much older age (Table 7).

Table 7. Soil concretions' ${ }^{14} \mathrm{C}$ date, y BP with depth and site (sampling date: 1997; year of ${ }^{14} \mathrm{C}$ measurements: 2005).

\begin{tabular}{|c|c|c|c|c|c|c|}
\hline $\begin{array}{l}\text { Site/Depth } \\
\text { (cm) }\end{array}$ & $\begin{array}{c}\text { Soil } \\
\text { Horizon }\end{array}$ & $\begin{array}{l}\delta^{13} \mathrm{C} \\
(\%)\end{array}$ & $\begin{array}{c}\text { Pedogenic } \\
\text { Carbonate (\%) }\end{array}$ & $\begin{array}{c}{ }^{14} \mathrm{C} \text { Age } \\
\left({ }^{14} \mathrm{C} \text { y BP }\right)\end{array}$ & $\begin{array}{c}\text { Percent } \\
\text { Modern (\%) }\end{array}$ & $\begin{array}{c}\Delta^{14} \mathrm{C} \\
(\%)\end{array}$ \\
\hline \multicolumn{7}{|l|}{ Fallow } \\
\hline \multicolumn{7}{|c|}{ Concretion (outside) } \\
\hline $190-200$ & $\mathrm{C} 2$ & -9.49 & 98 & $1909 \pm 40$ & 78 & -216.8 \\
\hline \multicolumn{7}{|c|}{ Concretion (inside) } \\
\hline 190-200 & $\mathrm{C} 2$ & -9.69 & 100 & $1693 \pm 39$ & 80 & -195.4 \\
\hline \multicolumn{7}{|l|}{ Cropland } \\
\hline \multicolumn{7}{|c|}{ Concretion } \\
\hline 180-190 & Bk2 & -9.68 & 100 & $2285 \pm 40$ & 75 & -252.6 \\
\hline
\end{tabular}

The interior of the concretion from the fallow site had the youngest ${ }^{14} \mathrm{C}$ age (Table 7). Earlier research by [31] reported that the mineralogical composition of concretions varied from low-magnesium calcite to pure calcite. Pedogenic carbonates are typically enriched in the heavy carbon isotope ${ }^{13} \mathrm{C}$ by $14-16 \%$ (depending on the temperature of carbonate formation) relative to coexisting $\mathrm{SOM}$, reflecting equilibrium isotopic fractionation between carbonate and $\mathrm{CO}_{2}$ and gaseous diffusion in the soil [58,59]. Assuming a formation temperature of $5.4{ }^{\circ} \mathrm{C}$ (the mean annual air temperature in the study area), the predicted $\delta^{13} \mathrm{C}$ values for pedogenic carbonates formed at deeper depths $(>30 \mathrm{~cm})$ in these soils with $\delta^{13} \mathrm{C}_{\mathrm{SOM}}$ values of -26 to $-27 \%$ would be -10 to $-11 \%$ [60-62]. The measured 
$\delta^{13} \mathrm{C}$ value of the soil carbonate concretion is consistent with the predicted values, reflecting its formation in equilibrium with soil $\mathrm{CO}_{2}$ in an ecosystem dominated by $\mathrm{C} 3$ plants at relatively cool temperatures. Radiocarbon dating of pedogenic carbonates traditionally was considered an unreliable dating technique in quaternary studies because of a possible "limestone dilution effect" $[58,60]$ or contamination. More recently, a series of studies has shown that pedogenic carbonate forms in isotopic equilibrium with soil $\mathrm{CO}_{2}$ and the dissolution of limestone or detrital carbonate have practically no effect on the carbon isotopic composition of pedogenic carbonate because of complete isotopic exchange with soil $\mathrm{CO}_{2}[59,61,63]$. These studies also have changed the way in which radiocarbon in soil is interpreted $[64,65]$. In general, as a soil ages, the radiocarbon age of SOM increases and so does the radiocarbon age of soil $\mathrm{CO}_{2}$, which is produced by microbial decomposition of SOM and root respiration [64]. As a result, pedogenic carbonate formed in equilibrium with soil $\mathrm{CO}_{2}$ at a particular time during a soil's development may have a radiocarbon age greater than the true age of the carbonate itself $[20,64,65]$. However, since most pedogenic carbonates collected for radiocarbon dating contain many generations of carbonates that formed at various times during the period of soil formation, the radiocarbon ages of such samples are always younger than the true age of the soil $[20,64,65]$. Thus, the much younger radiocarbon ages of the carbonate concretions found in the cultivated Russian Chernozem suggest that they were formed in equilibrium with soil $\mathrm{CO}_{2}$ much later in the soil.

\section{Discussion}

Russian grasslands (steppe) have undergone considerable conversion from a native to a cultivated state, which has resulted in well-documented SOC losses [1,38]. Previous research has focused on estimating SOC, SIC, and TC [32,38] stocks in these soils without considering the consequences of cultivation on the diagnostic horizons within the soil profile. Soil research often has been based on traditional pedological principles instead of using experimental pedology, which is more applicable to cultivated soils. Experimental pedology can help our understanding of "soil memory" $[25,66]$.

This study employed principles of experimental pedology to examine the effect of cultivation on pedological changes within the soil profile with consequent changes in the diagnostic soil horizons and characteristics at three sites: a native grassland field (not cultivated for at least 300 years), an adjacent 50-year continuous fallow field in the V.V. Alekhin Central-Chernozem Biosphere State Reserve in the Kursk region of Russia (UNESCO-MAB Biosphere Reserve), and a cropland in the Experimental Station of the Kursk Institute of Agronomy and Soil Erosion Control.

Cultivation resulted in morphological/diagnostic changes in the soil profile (conversion of A to Ap horizon; conversion of Bw to Bk horizon) in a 50-year period (Table 4) [57]. This study is based on three representative soil profiles representing native, fallow, and cropland sites, therefore, it is reasonable to question how representative these soil profiles are compared to the other four soil profiles in each site. Soil inorganic carbon distribution with depth in the representative soil profiles falls in the ranges reported in Table 8, which summarizes data using five soil profiles per site with a total of 15 soil profiles. For example, depth to carbonates is comparable in the following way: native $(150 \mathrm{~cm}$ falls in the range of $112 \pm 47 \mathrm{~cm}$ ), fallow $(80 \mathrm{~cm}$ falls in the range of $76 \pm 23 \mathrm{~cm}$ ), and cropland $(30 \mathrm{~cm}$ falls in the range of $34 \pm 5$ ). The native site had one of the soil profiles that exhibited signs of bioturbation ("krotovinas"), which is a common phenomenon in the steppe landscapes [45]. In this soil profile, the depth to carbonates was $30 \mathrm{~cm}$. Exclusion of this profile from depth to carbonates in the native site would have resulted in $133 \pm 10 \mathrm{~cm}$ based on the remaining four soil profiles.

The differences between cultivated and native sites show that cultivated sites have an increase of above 1\% in SIC in 100-140 depth increment, which corresponds to the bulk and pedogenic carbonates' accumulations. A study by [32] proposed an "anthropogenic" model to describe carbonate formation as a result of human activities (e.g., cultivation, fertilization), which can lead to conversion of $\mathrm{Bw}$ horizon in native grassland to Bk horizon as demonstrated in the fallow and cropland sites. This study shows that relatively rapid changes in SIC can occur in the subsoil B horizons, which tend to have "longer memories" than surface A horizons [67]. These rapid changes in inorganic carbon 
have been demonstrated in urban soils where additions of $\mathrm{Ca} / \mathrm{Mg}$-rich amendments caused creation of carbonates that served to capture and store atmospheric carbon [68]. Pedological evidence of anthropogenic and agrogenic roles in soil profile modification were documented in various countries and soils $[69,70]$. For example, [69] reported human-induced changes in the classification of soils in Ireland: From peats (Histosols) and peaty podzolised gleys (Haplaquods) to plaggen soils (Plaggepts). A study by [70] described ancient soils with plaggen and agric horizons in the Andes of Southern Peru. Carbonate precipitation in soils is a complex process, which can be natural (e.g., caliche etc.) or human-induced. Mikhailova and Post [32] proposed an "anthropogenic" model of carbonate formation as a result of human activities, including cultivation, which leads to the destruction of roots rich in basic nutrients (especially $\mathrm{Ca}^{2+}$ ), contributing to the carbonate formation in the soil and subsequent changes (e.g., hydrologic etc.) in the soil profile (Figure 4). Human-induced calcic horizon (Bk) can form in less than 50 years of cultivation as demonstrated by conversion of native grassland to continuous fallow (no input of plant material) in this unique experiment preserved at the V.V. Alekhin Central-Chernozem Biosphere State Reserve in the Kursk region of Russia (UNESCO-MAB Biosphere Reserve).

Table 8. Soil inorganic carbon (mean \pm standard deviation) distribution with depth.

\begin{tabular}{|c|c|c|c|c|c|c|}
\hline \multirow[b]{2}{*}{ Depth (cm) } & \multicolumn{3}{|c|}{ Soil Inorganic Carbon (SIC) (\%) } & \multicolumn{3}{|c|}{ Difference in Soil Inorganic Carbon (SIC) (\%) } \\
\hline & $\begin{array}{l}\text { Native } \\
(n=5)\end{array}$ & $\begin{array}{l}\text { Fallow } \\
(n=5)\end{array}$ & $\begin{array}{l}\text { Cropland } \\
(\mathrm{n}=5)\end{array}$ & Fallow-Native & Cropland-Native & Cropland-Fallow \\
\hline $0-10$ & $0 \pm 0$ & $0 \pm 0$ & $0 \pm 0$ & 0 & 0 & 0 \\
\hline $10-20$ & $0 \pm 0$ & $0 \pm 0$ & $0 \pm 0$ & 0 & 0 & 0 \\
\hline $20-30$ & $0 \pm 0$ & $0 \pm 0$ & $0 \pm 0$ & 0 & 0 & 0 \\
\hline $30-40$ & $0.13 \pm 0.27$ & $0 \pm 0$ & $0.32 \pm 0.27$ & -0.13 & 0.20 & 0.32 \\
\hline $40-50$ & $0.09 \pm 0.17$ & $0.02 \pm 0.04$ & $0.47 \pm 0.30$ & -0.07 & 0.39 & 0.46 \\
\hline $50-60$ & $0.16 \pm 0.31$ & $0.17 \pm 0.38$ & $0.50 \pm 0.21$ & 0.01 & 0.34 & 0.33 \\
\hline $60-70$ & $0.12 \pm 0.24$ & $0.28 \pm 0.63$ & $0.56 \pm 0.29$ & 0.16 & 0.44 & 0.28 \\
\hline $70-80$ & $0.09 \pm 0.19$ & $0.29 \pm 0.54$ & $0.93 \pm 0.35$ & 0.20 & 0.84 & 0.64 \\
\hline $80-90$ & $0.13 \pm 0.26$ & $0.59 \pm 0.68$ & $1.05 \pm 0.37$ & 0.46 & 0.92 & 0.46 \\
\hline $90-100$ & $0.13 \pm 0.27$ & $1.02 \pm 0.65$ & $1.43 \pm 0.27$ & 0.89 & 1.30 & 0.41 \\
\hline $100-110$ & $0.15 \pm 0.31$ & $1.31 \pm 0.35$ & $1.55 \pm 0.16$ & 1.16 & 1.40 & 0.24 \\
\hline $110-120$ & $0.13 \pm 0.25$ & $1.61 \pm 0.16$ & $1.67 \pm 0.22$ & 1.48 & 1.54 & 0.06 \\
\hline $120-130$ & $0.38 \pm 0.50$ & $1.65 \pm 0.16$ & $1.74 \pm 0.14$ & 1.27 & 1.36 & 0.09 \\
\hline $130-140$ & $0.47 \pm 0.51$ & $1.59 \pm 0.15$ & $1.62 \pm 0.16$ & 1.12 & 1.16 & 0.04 \\
\hline $140-150$ & $0.61 \pm 0.40$ & $1.45 \pm 0.20$ & $1.57 \pm 0.06$ & 0.84 & 0.96 & 0.12 \\
\hline $150-160$ & $1.06 \pm 0.18$ & $1.41 \pm 0.32$ & $1.49 \pm 0.17$ & 0.35 & 0.43 & 0.08 \\
\hline $160-170$ & $1.29 \pm 0.13$ & $1.41 \pm 0.24$ & $1.49 \pm 0.05$ & 0.12 & 0.20 & 0.09 \\
\hline $170-180$ & $1.23 \pm 0.18$ & $1.23 \pm 0.18$ & $1.44 \pm 0.09$ & -0.01 & 0.20 & 0.21 \\
\hline $\begin{array}{c}\text { Depth to } \\
\text { carbonates }(\mathrm{cm})\end{array}$ & $112 \pm 47$ & $76 \pm 23$ & $34 \pm 5$ & - & - & - \\
\hline
\end{tabular}
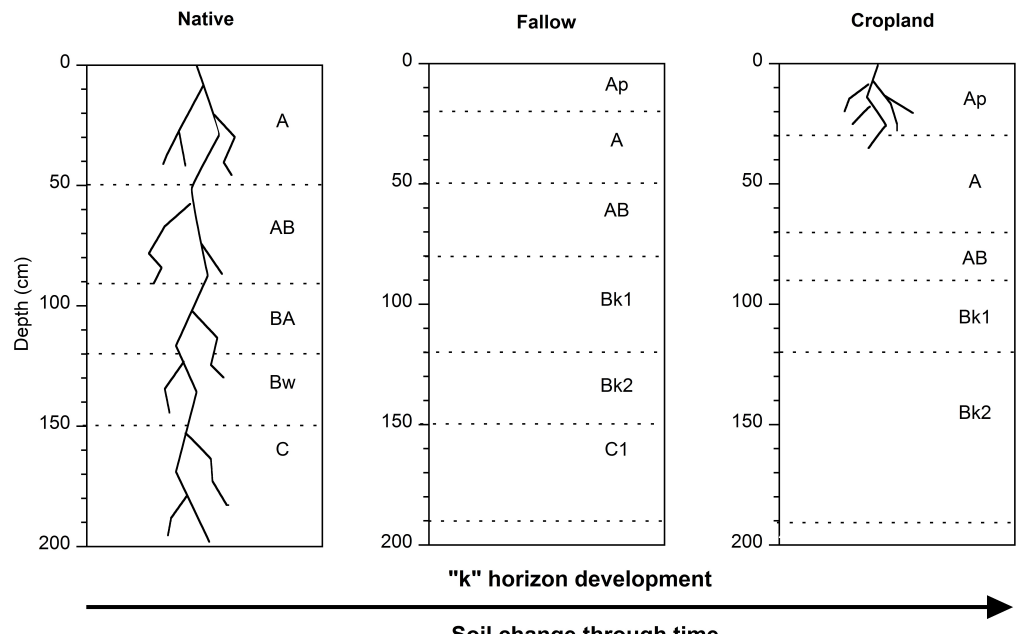

Figure 4. Model of carbonate horizon formation in soils through time as a result of cultivation of native grasslands. 


\section{Conclusions}

Cultivation had a remarkable effect on the radiocarbon age of the Russian Chernozem due to changes in SOC, SIC, and TC concentrations. The radiocarbon age $\left({ }^{14} \mathrm{C}\right.$ date, $\left.\mathrm{BP}\right)$ of soil carbon was highly variable: In the native grassland field, it varied from post-bomb (A-horizon) to $8011 \pm 54$ y BP (C-horizon); in the continuous fallow, it varied from $1569 \pm 41$ y BP (Ap-horizon) to 11,380 \pm 180 y BP (C1-horizon); and in the cropland, it varied from $1055 \pm 38$ y BP (Ap-horizon) to 11,805 \pm 68 y BP (Ck-horizon). The presence of carbonates (including pedogenic) impacted the radiocarbon dating of soil as indicated by radiocarbon ages of the soil samples with and without carbonates. Cultivation resulted in morphological/diagnostic changes in the soil profile (conversion of A to Ap horizon; conversion of $\mathrm{Bw}$ to $\mathrm{Bk}$ horizon) in a 50-year period. This change is supported by radiocarbon dating of SOC and pedogenic carbonates' distribution within the soil profile. The concentration of pedogenic carbonates was highly variable: in the native grassland, it was $27 \%$ (C-horizon); in the continuous fallow, it varied from 53\% (Bk1-horizon) to 72\% (C2-horizon), and in the cropland, it varied from 85\% (A-horizon) to $10 \%$ (Ck-horizon). The radiocarbon age differences between soil carbonates and SOM reflect differences in the processes and time scales of their formations.

Author Contributions: Conceptualization, E.A.M.; methodology, E.A.M., Y.W., R.B.B., J.M.G.; formal analysis, E.A.M.; resources, E.A.M.; writing—original draft preparation, E.A.M.; writing—review and editing, E.A.M., O.S.K., M.A.S., Z.S.; visualization, E.A.M., M.P.C., C.J.P.; supervision, E.A.M.; project administration, E.A.M.; funding acquisition, E.A.M., R.B.B.

Funding: This research was funded by National Science Foundation (NSF Award No. 0340534).

Acknowledgments: Authors wish to acknowledge the many people and organizations in Russia who have contributed to this study. We would like to thank the V.V. Alekhin Central-Chernozem Biosphere State Reserve, especially N.A. Maleshin, N.I. Zolotuhin, and O.S. Boiko, and the Russian Institute of Agronomy and Soil Erosion Control in Kursk and its director, V.M. Volodin. The authors greatly appreciate field assistance by I.I. Vasenev, E.G. Vaseneva, E.K. Daineko, K. Bryant, and A. Ivanov. Carbon dating was performed at the National Science Foundation/Arizona Accelerator Mass Spectrometry Laboratory, University of Arizona, Tuscon, Arizona.

Conflicts of Interest: The authors declare no conflict of interest.

\section{References}

1. Torn, M.S.; Lapenis, A.G.; Timofeev, A.; Fischer, M.L.; Babikov, B.V.; Harden, J.W. Organic carbon and carbon isotopes in modern and 100-year-old-soil archives of the Russian steppe. Glob. Chang. Biol. 2002, 8, 941-953. [CrossRef]

2. Willms, W.; Adams, B.; McKenzie, R. Overview: Anthropogenic Changes of Canadian Grasslands. In Arthropods of Canadian Grasslands (Volume 2): Inhabitants of a Changing Landscape; Floate, K.D., Ed.; Biological Survey of Canada: Ottawa, ON, Canada, 2011; pp. 1-22, ISBN 978-0-9689321-5-5.

3. Paul, E.A.; Follett, R.F.; Leavitt, S.W.; Halvorson, A.; Peterson, G.A.; Lyon, D.J. Radiocarbon dating for determination of soil organic matter pool sizes and dynamics. Soil Sci. Soc. Am. J. 1997, 61, 1058-1067. [CrossRef]

4. Scharpenseel, H.W.; Becker-Heidmann, P. Twenty-five years of radiocarbon dating soils: Paradigm of erring and learning. Radiocarbon 1992, 34, 541-549. [CrossRef]

5. Rethemeyer, J.; Grootes, P.M.; Bruhn, F.; Andersen, N.; Nadeau, M.J.; Kramer, C.; Gleixner, G. Age heterogeneity of soil organic matter. Nucl. Instrum. Methods Phys. Res. B 2004, 223-224, 521-527. [CrossRef]

6. Rethemeyer, J.; Kramer, C.; Gleixner, G.; John, B.; Yamashita, T.; Flessa, H.; Andersen, N.; Nadeau, M.; Grootes, P.M. Transformation of organic matter in agricultural soils: Radiocarbon concentration versus soil depth. Geoderma 2005, 128, 94-105. [CrossRef]

7. Chendev, Y.G.; Khokhlova, O.S.; Alexandrovskiy, A.L. Agrogenic evolution of automorphic Chernozems in the forest-steppe zone (Belgorod Oblast). Eurasian Soil Sci. 2017, 5, 499-514. [CrossRef]

8. Wang, H.; Stumf, A.J.; Kumar, P. Radiocarbon and stable isotopes of labile and inert organic carbon in the Critical Zone Observatory in Illinois, USA. Radiocarbon 2018, 60, 989-999. [CrossRef]

9. Wang, Y.; Amundson, R.; Trumbore, S. Radiocarbon dating of soil organic matter. Quat. Res. 1996, 45, 282-288. [CrossRef] 
10. Perrin, R.M.S.; Willis, E.H.; Hodge, D.A.H. Dating of humus podzols by residual radiocarbon activity. Nature 1964, 202, 165-166. [CrossRef]

11. Scharpenseel, H.W. Radiocarbon dating of soils. Sov. Soil Sci. 1971, 3, 76-83.

12. Scharpenseel, H.W. Radiocarbon dating of soils-problems, troubles, hopes. In Paleopedology-Origin, Nature and Dating of Paleosols; Yaalon, D.H., Ed.; International Society of Soil Science and Israel Univ. Press: Jerusalem, Israel, 1971; pp. 77-87.

13. Scharpenseel, H.W. Natural radiocarbon measurement on soil organic matter fractions and on soil profiles of different pedogenesis. In Proceedings of the 8th International Conference on Radiocarbon Dating, Lower Hutt, New Zealand, 18-25 October 1972; Volume 1, pp. 382-394.

14. Scharpenseel, H.W. Soil fraction dating. In Radiocarbon Dating; Berger, R., Suess, H.E., Eds.; Univ. of California Press: Berkeley, CA, USA, 1976; pp. 277-283.

15. Cherkinsky, A.E.; Brovkin, V.A. A model of humus formation in soils based on radiocarbon data of natural ecosystems. Radiocarbon 1991, 33, 186-187.

16. Rutberg, R.L.; Schimel, D.S.; Hajdas, I.; Broecker, W.S. The effect of tillage on soil organic matter using ${ }^{14}$ C: A case study. Radiocarbon 1996, 38, 209-217. [CrossRef]

17. Fazle Rabbi, S.M.; Hua, Q.; Daniel, H.; Lockwood, P.V.; Wilson, B.R.; Young, I.M. Mean residence time of soil organic carbon in aggregates under contrasting land uses based on radiocarbon measurements. Radiocarbon 2013, 55, 127-139. [CrossRef]

18. Orlova, L.A.; Panychev, V.A. The reliability of radiocarbon dating buried soils. Radiocarbon 1993, 35, 369-377. [CrossRef]

19. Wang, Y.; McDonald, E.; Amundson, R.; McFadden, L.; Chadwick, O. An isotopic study of soils in chronological sequences of alluvial deposits, Providence Mountains, California. Geol. Soc. Am. Bull. 1996, 108, 379-391. [CrossRef]

20. Bowler, I.M.; Polach, H.A. Radiocarbon analyses of soil carbonates: An evaluation from paleosols in southeastern Australia. In Paleopedology: Origin, Nature and Dating of Paleosols; Yaalon, D.H., Ed.; International Society of Soil Science: Jerusalem, Israel, 1971; pp. 97-108.

21. Groshans, G.R.; Mikhailova, E.A.; Post, C.J.; Schlautman, M.A. Accounting for soil inorganic carbon in the ecosystem services framework for the United Nations sustainable development goals. Geoderma 2018, 324, 37-46. [CrossRef]

22. Goddard, M.A.; Mikhailova, E.A.; Post, C.J.; Schlautman, M.A. Atmospheric $\mathrm{Mg}^{2+}$ wet deposition within the continental United States and implications for soil inorganic carbon sequestration. Tellus Ser. B 2007, 59, 50-56. [CrossRef]

23. Goddard, M.A.; Mikhailova, E.A.; Post, C.J.; Schlautman, M.A.; Galbraith, J.M. Continental United States atmospheric wet calcium deposition and soil inorganic carbon stocks. Soil Sci. Soc. Am. J. 2009, 73, 989-994. [CrossRef]

24. Mikhailova, E.A.; Goddard, M.A.; Post, C.J.; Schlautman, M.A.; Galbraith, J.M. Potential contribution of combined atmospheric $\mathrm{Ca}^{2+}$ and $\mathrm{Mg}^{2+}$ wet deposition within the continental U.S. to soil inorganic carbon sequestration. Pedosphere 2013, 23, 808-814. [CrossRef]

25. Monger, H.C.; Rachal, D.M. Soil and landscape memory of climate change: How sensitive, how connected? In New Frontiers in Paleopedology and Terrestrial Paleoclimatology: Paleosols and Soil Surface Analog Systems; Driese, S.G., Nordt, L.C., Eds.; Society for Sedimentary Geology Special Publication 104; Society for Sedimentary Geology: Tulsa, OK, USA, 2013; pp. 63-70.

26. Monger, C.H. Pedogenic carbonate: Links between biotic and abiotic $\mathrm{CaCO}_{3}$. 2002, p. 897-891 to 897-9. In Proceedings of the 17th WCSS (World Congress of Soil Science), Bangkok, Thailand, 14-21 August 2002.

27. Schlesinger, W.H. The formation of caliche in soils of the Mojave Desert, California. Geochim. Cosmochim. Acta 1985, 49, 57-66. [CrossRef]

28. Wang, J.; Monger, C.; Wang, X.; Serena, M.; Leinauer, B. Carbon sequestration in response to grassland-shrubland-turfgrass conversions and a test for carbonate biomineralization in desert soils, New Mexico, USA. Soil Sci. Soc. Am. J. 2016, 80, 1591-1603. [CrossRef]

29. Landi, A.; Mermut, A.R.; Anderson, D.W. Origin and rate of pedogenic carbonate accumulation in Saskatchewan soils, Canada. Geoderma 2003, 117, 143-156. [CrossRef] 
30. Stevenson, B.A.; Kelly, E.F.; McDonald, E.V.; Busacca, A.J. The stable carbon isotope composition of soil organic carbon and pedogenic carbonates along a bioclimatic gradient in the Palouse region, Washington State, USA. Geoderma 2005, 124, 37-47. [CrossRef]

31. Mikhailova, E.A.; Post, C.J.; Magrini-Bair, K.; Castle, J.W. Pedogenic carbonate concretions in the Russian Chernozem. Soil Sci. 2006, 171, 981-991. [CrossRef]

32. Mikhailova, E.A.; Post, C.J. Effects of land use on soil inorganic carbon stocks in the Russian Chernozem. JEQ 2006, 35, 1384-1388. [CrossRef] [PubMed]

33. Wu, L.; Wood, Y.; Jiang, P.; Li, L.; Pan, G.; Lu, J.; Chang, A.C.; Enloe, H.A. Carbon sequestration and dynamics of two irrigated agricultural soils in California. Soil Sci. Soc. Am. J. 2008, 72, 808-814. [CrossRef]

34. Han, X.; Gao, G.; Chang, R.; Li, Z.; Ma, Y.; Wang, S.; Wang, C.; Lü, Y.; Fu, B. Changes in soil organic and inorganic carbon stocks in deep profiles following cropland abandonment along a precipitation gradient across the Loess Plateau of China. Agric. Ecosyst. Environ. 2018, 258, 1-13. [CrossRef]

35. Wu, H.; Guo, Z.; Gao, Q.; Peng, C. Distribution of soil inorganic carbon storage and its changes due to agricultural land use activity in China. Agric. Ecosyst. Environ. 2009, 129, 413-421. [CrossRef]

36. Mayer, S.; Schwindt, D.; Steffens, M.; Völkel, J.; Kögel-Knabner, I. Drivers of organic carbon allocation in a temperate slope-floodplain catena under agricultural use. Geoderma 2018, 327, 63-72. [CrossRef]

37. Hallsworth, E.G.; Crawford, D.V. Experimental Pedology; Butterworths: London, UK, 1965.

38. Mikhailova, E.A.; Bryant, R.B.; Vassenev, I.I.; Schwager, S.J.; Post, C.J. Cultivation effects on soil carbon and nitrogen contents at depth in the Russian Chernozem. Soil Sci. Soc. Am. J. 2000, 64, 738-745. [CrossRef]

39. Chichagova, O.A. Radiocarbon Dating of Humus of Soils: Methods and Applications in Pedology and Palaeogeography; Gerasimov, I.P., Targuljan, V.O., Eds.; Iszd-vo Nauka: Moscow, Russia, 1985; 155p. (In Russian)

40. Margolina, N.Y.; Alexandrovski, A.L.; Ilichev, B.A.; Cherkinsky, A.E.; Chichagova, O.A. Age and Evolution of Chernozems; Iszd-vo Nauka: Moscow, Russia, 1988; 144p. (In Russian)

41. Köppen, W. Klassification der Klimate nach Temperatur, Niederschlag and Jahreslauf. Petermanns Geographische Mitteilungen 1918, 64, 193-203, 243-248. Available online: http:/ / koeppen-geiger.vu-wien.ac. at/koeppen.htm (accessed on 20 July 2018).

42. Alekhin, V.V. Central-Chernozem Biosphere State Reserve. Letopis' Prirody (Annual Scientific Reports) 1947-1997; Central-Chernozem Biosphere State Reserve: Kursk, Russia, 1997; Volume 1-63.

43. Soil Survey Staff. Keys to Soil Taxonomy, 8th ed.; USDA-NRCS: Washington, DC, USA, 1998.

44. Stolbovoi, V. Soils of Russia: Correlated with the Revised Legend of the FAO Soil Map of the World and World Reference Base for Soil Resources; International Institute for Applied Systems Analysis: Laxenburg, Austria, 2000.

45. Pietsch, D. Krotovinas-Soil archives of steppe landscape history. Catena 2013, 104, 257-264. [CrossRef]

46. Vinogradov, B.V. Aerospace studies of protected natural areas in the USSR. In Conservation, Science and Society (Natural Resources Research, XXI, Volmue 2); UNESCO-UNEP: London, UK, 1984; pp. 435-448.

47. Ryabov, V.A. Climatological characteristic of the Central-Chernozem Reserve. In Transactions of the Central-Chernozem State Biosphere Reserve; Alekhin, V.V., Ed.; Gidrometeoizdat: Leningrad, Israel, 1979; Volume 12, pp. 5-72. (In Russian)

48. Mikhailova, E.A.; Bryant, R.B.; Cherney, D.J.R.; Post, C.J.; Vassenev, I.I. Botanical composition, soil and forage quality under different management regimes in Russian grasslands. Agric. Ecosyst. Env. 2000, 80, 213-226. [CrossRef]

49. Mikhailova, E.A.; Bryant, R.B.; DeGloria, S.D.; Post, C.J.; Vassenev, I.I. Modeling soil organic matter dynamics after conversion of native grassland to long-term continuous fallow using the CENTURY model. Ecol. Model. 2000, 132, 247-257. [CrossRef]

50. McLean, E.O. Soil pH and lime requirement. In Methods of Soil Analysis. Part 2, 2nd ed.; Agronomy Monograph 9; Page, A.L., Ed.; ASA and SSSA: Madison, WI, USA, 1982; pp. 199-224.

51. Nelson, R.E. Carbonate and gypsum. In Methods of Soil Analysis. Part 2, 2nd ed.; Agronomy Monograph 9; Page, A.L., Ed.; ASA and SSSA: Madison, WI, USA, 1982; pp. 181-197.

52. Linick, T.W.; Jull, A.J.T.; Toolin, L.J.; Donahue, D.J. Operation of the NSF-Arizona accelerator facility for radioisotope analysis and results from selected collaborative research projects. In Proceedings of the International 14C Conference, 12th Proceedings Radiocarbon, Trondheim, Norway, 24-28 June 1985; Stuiver, M., Kra, R.S., Eds.; Volume 28, pp. 522-533.

53. Donahue, D.J.; Linick, T.W.; Jull, A.J.T. Isotope-ratio and background corrections for accelerator mass spectrometry radiocarbon measurements. Radiocarbon 1990, 32, 135-142. [CrossRef] 
54. Stuiver, M.; Polach, H. Reporting of ${ }^{14} \mathrm{C}$ data. Radiocarbon 1977, 19, 355-363. [CrossRef]

55. Reimer, P.J.; Brown, T.A.; Reimer, R.W. Discussion: Reporting and calibration of post-bomb ${ }^{14} \mathrm{C}$ data. Radiocarbon 2004, 46, 1299-1304. [CrossRef]

56. Salomons, W.; Mook, W.G. Isotope geochemistry of carbonate dissolution and reprecipitation in soils. Soil Sci. 1976, 122, 15-24. [CrossRef]

57. Soil Survey Staff. Keys to Soil Taxonomy, 12th ed.; USDA-Natural Resources Conservation Service: Washington, DC, USA, 2014.

58. Bartlett, H.H. Radiocarbon datability of peat, marl, caliche, and archaeological materials. Science 1951, 114, 55-56. [CrossRef]

59. Cerling, T.E.; Quade, J.; Wang, Y.; Bowman, J.R. Carbon isotopes in soils and paleosols as ecology and paleoecology indicators. Nature 1989, 341, 138-139. [CrossRef]

60. Broecker, W.S.; Walton, A. The geochemistry of $\mathrm{C}^{14}$ in fresh-water systems. Geochim. Cosmochim. Acta 1959, 16, 15-38. [CrossRef]

61. Cerling, T.E. The stable isotopic composition of modern soil carbonate and its relationship to climate. Earth Planet. Sci. Lett. 1984, 71, 229-240. [CrossRef]

62. Deines, P.; Langmuir, D.; Harmon, R.S. Stable carbon isotope ratios and the existence of a gas phase in the evolution of carbonate ground waters. Geochim. Cosmochim. Acta 1974, 1147-1164. [CrossRef]

63. Quade, J.; Cerling, T.E.; Bowman, J.R. Systematic variations in the carbon and oxygen isotopic composition of pedogenic carbonate along elevation transects in the southern Great Basin, United States. Geol. Soc. Am. Bull. 1989, 101, 464-475. [CrossRef]

64. Wang, Y.; Amundson, R.; Trumbore, S. A model for soil ${ }^{14} \mathrm{CO}_{2}$ and its implications for using ${ }^{14} \mathrm{C}$ to date pedogenic carbonate. Geochim. Cosmochim. Acta 1994, 58, 393-399.

65. Amundson, R.G.; Lund, L.J. The stable isotope chemistry of a native and irrigated Typic Natrargid in the San-Joaquin Valley of California. Soil Sci. Soc. Am. J. 1987, 51, 761-767. [CrossRef]

66. Targulian, V.O.; Goryachkin, S.V. Soil memory: Types of record, carriers, hierarchy and diversity. Rev. Mex. Cienc. Geol. 2004, 21, 1-8.

67. Gerasimova, M.; Lebedeva, M. Contribution of micromorphology to classification of aridic soils. In New Trends in Soil Micromorphology; Kapur, S., Stoops, G., Eds.; Springer: Berlin/Heidelberg, Germany, 2008; pp. 151-162.

68. Washbourne, C.-L.; Renforth, P.; Manning, D.A.C. Investigating carbonate formation in urban soils as a method for capture and storage of atmospheric carbon. Sci. Total Environ. 2012, 431, 166-175. [CrossRef]

69. Conry, M.J. Pedological evidence of man's role in soil profiles modification in Ireland. Geoderma 1972, 8, 139-146. [CrossRef]

70. Sandor, J.A.; Eash, N.S. Ancient agricultural soils in the Andes of Southern Peru. Soil Sci. Soc. Am. J. 1995, 59, 170-179. [CrossRef]

(C) 2018 by the authors. Licensee MDPI, Basel, Switzerland. This article is an open access article distributed under the terms and conditions of the Creative Commons Attribution (CC BY) license (http:/ / creativecommons.org/licenses/by/4.0/). 